\title{
The Human Rights Climate in Higher Education Institutions in Jordan
}

\author{
Naser Al-Sharah ${ }^{1}$, Barak Sanat Alrashidi ${ }^{2} \&$ Faisal Khlaif Al-Sharaah ${ }^{3}$ \\ ${ }^{1}$ Al-Balqa Applied University, Amman College University, Salt, Jordan \\ ${ }^{2}$ The Public Authority for Applied Education and Training, Adailiyah, Kuwait \\ Correspondence: Naser Al-Sharah, Al-Balqa Applied University, Irbid College University, Salt, Jordan.
}

Received: September 26, 2018 Accepted: October 29, 2018 Online Published: November 19, 2018

doi:10.5539/res.v10n4p183

URL: https://doi.org/10.5539/res.v10n4p183

\begin{abstract}
This study aimed to uncover the reality of the human rights climate in higher education institutions in Jordan. It used the descriptive survey approach and applied the University of Minnesota Scale (Taking the Human Rights Temperature of Your School). The study sample consisted of (521) male and female students and teachers. Results showed that the impact of the human rights climate is present at higher education institutions in Jordan at a medium degree of (3.14) and a standard deviation of (0.39). They've also shown that there are no statistically significant differences at the level of significance $(\alpha \leq 0.05)$ regarding the impact of the human rights climate on higher education institutions in Jordan due to the variables of role (students, teachers) and gender (male, female).
\end{abstract}

Keywords: human rights, human rights climate, higher education institutions, Jordan

\section{Introduction}

Education has been a life-long process of learning that was - and still is - crucial to the advancement of citizenship in democratic and equitable societies. If an educational institution was to teach students how to be democratic citizens, it has to affirm that the approach they follow does not break the principles of human rights, since democracy and human rights education represent three essential dimensions; the first one is that teaching human rights to inform people of their rights. The second dimension is to make them aware of how to stand up for their rights. The third is creating appropriate conditions within an educational environment that allow people to report and reflect their fears and familiarizing them with others' human rights in hopes of encouraging responsible actions as well as securing everyone's rights. Upon these dimensions, human rights education can be described as a rational effort to familiarize people of their own rights and obligations as well as others' rights in hopes of encouraging responsible actions as well as securing everyone's rights (Gündoğdu, 2011).

Human rights can be referred to as those rights, which belong to every human being despite their gender, colour, race, ethnicity, etc. They embody the basic standards that one cannot achieve human dignity without; these rights are universal to everyone, and therefore, are given to the person the moment they are born, and without those rights, one would stop being a human being, as those rights are indispensable and it is not in anyone's power to deprive a person of them; hence, human rights are considered interdependent, which implies that they are a part of a complementary agenda (Nduta, 2015).

Human rights education involves more not just teaching students about their rights or memorizing legal texts by heart. It must become a lifestyle and a philosophy for on-campus students and the core of the educational institution and the content of its formal curriculum. In addition, it must be associated with understanding and sympathizing with notions such as democracy, liberty, justice, peace, responsibilities, rights, and unity. In addition, it must help people acquire certain skills, specifically (Tarrow, 2014):

- Skills associated with the development of language, like written and oral and oral expressions, as well as the capability to discuss and listen;

- Skills associated with judgment, such as collecting and analyzing material from diverse sources, detecting bias and favouritism (including mass media), in addition to the capability to reach stable and stable decisions;

- Social skills, which include recognizing and accepting others' dissimilarities, in addition to being able to develop positive and just relations with others;

- Skills associated with taking actions, such as resolving conflicts in peaceful ways, taking responsibility for one's actions, contributing to group decisions, and recognizing as well making use of all necessary means to preserve human rights at the local, national, and international levels. 
Human rights education is not merely about human rights, it is there to help people appreciate the importance of human rights, practice these rights in their lifestyles, and take actions that would encourage and protect others' rights on the personal, local, national, and international levels. Human rights education also plays an important role in the improvement of the lives of both people and society in a direct manner. Together the universal human rights to education, the obligations related to the aims of education and the freedom of educational choice, as explained in educational articles concerning human rights conventions, have become part of the grant of human rights in education standards (Patel, 2007).

Principles of Human rights education have been included within international human rights treaties with the purpose of "sharing knowledge, imparting skills, and forming attitudes to stimulate action that aims to reinforce respect of human rights, freedoms, open-mindedness, equality, and peace among people within societies and among nations." However, teachers still contemplate how to incorporate international human rights within post-secondary programs. Albeit, integrating Human rights education within post-secondary courses, particularly at traditional institutions that emphasize rigid disciplinary borders, can be a challenge. If these types of barriers can be navigated or mitigated, it is important that advocates work collaboratively to network, disseminate, and share effective measures that will ultimately elevate the awareness and implementation of Human rights education in academia. To that end, it is hoped that the distribution of findings from this study will spark interest and efforts that will motivate the 'movers' to instil procedures and policies in their individual jurisdiction (Lynch, 2017).

There has been a rarity in researches and literature regarding human rights as well as their global dispersion during institutions of higher education. Thus, such analytical descriptive research was commenced in order to acquire a greater realizing of the reality of the human rights' climate on higher education institutions. The research will explore and attempt to define this impact of human rights on higher education institutions, and how students and teachers alike have merged them into their theoretical and practical work experience and how applicable they are.

\section{Background}

\subsection{Human Rights}

Human rights have long been an important element of democratic communities. This subject as well associated with ethical, international, multicultural, and peace education. Written constitutions contain a group of rights, where the most important of those rights was official within the U.S. Constitution and were adopted by the French National Gathering in its declaration of rights of man and citizens. Human rights and human rights education was brought into the light and focused on Right after ending the 2nd World War and surfaced along with the establishment of the United Nations, which came up with the global announcement of human rights. Furthermore, the European Convention on Human rights has inserted individual and social rights, which later became the foundation of the European Court of human rights (Gündoğdu, 2011).

Human rights are presently approved by all over the world as thoughts to be followed by human societies to which a large, increasing number of devices, bodies, and techniques were created in both national and international stages in order to perform and save these rights. The concept of human rights concentrates upon the idea that people have rights because of their humanity. It's been shown from the western point of view that human rights are taken from the nature of rights' concept of natural law philosophy of the 17th and 18th centuries, the main struggle was that rights were not man made but were written down by God. In addition, they are natural privileges are given to people just because they are a human. (Mubangizi and Kaya, 2015).

According to the United Nation (2018), human rights are the rights that are inherited for every single human being, irrespective of his or her race, place of residence, gender, ethnicity, colour, faith, language or any other category that defines a person. All people have an equal right to be authorized to their human rights without any differentiation. Given that, all these rights are interconnected, interdependent, and inseparable. These universally approved rights are often expressed and assured with the aid of law in the method of agreements, conventional global law, universal ideologies, as well as numerous additional sources of global law. Universal human rights law can determine government responsibilities and influences these administrations to act in a specific method or cease others for the sake of encouraging and defending human rights and the essential liberties of both persons and groups alike.

Thus, human rights are recognized by way of the rights that given to individuals for being a human being, which is the ultimate and only qualification that needs to be retained to enjoy having human rights. (Mubangizi, 2013). So as to be placed into the active process, human rights have been pre-set in many forms mentioned as human rights instruments, which consist of contracts, agreements, treaties, protocols, values, constitutions, resolutions and affirmations. Which mean that it become recognized more largely than previously and being given legal support and more acknowledgement (Mubangizi and Kaya, 2015).

Human rights are rightfully guaranteed to individuals through human rights law, it protects persons and groups alike 
against deeds that aim to hamper the essential liberties and human dignity. These rights are spoken through agreements, traditional global law, forms of principles, and other foundations of law. The laws of human rights place commitments on concerned parties to behave in a specific manner and forbid them from exercising in particular activities. Nevertheless, the law is not the one that establishes human rights; they are simply inheritable entitlements, which are given to every person for being human. The missions of those agreements and further sources of law usually aid to defend individuals and groups' rights formally against activities or gave up of activities by governments which might affect parties' pleasure of their human rights.

Based on the Office of the United Nations High Commissioner for human rights (2002), those are a number of the most fundamental features:

- Human rights had been based on self-respect and the value of each individual;

- Human rights are global, which mean that they are applicable to absolutely everyone without any discrimination.

- Human rights are absolute, which means that nobody could take another person's human way from the other expect in certain situations, such as having a person's liberty restrained if the said person was pleaded guilty of an offence as decided by a judge;

- Human rights are inseparable, interconnected, and interdependent, simply because it is far inadequate to accept some human rights and not others. Practically, breaking one right will undeniably have an effect on the respect of many other rights. Therefore, the whole human rights have to be realized through the same level of importance and to be equally crucial to respect them to emphasize self-respect as well as worth of people.

The human rights act took effect in the United Kingdom at 2000, during which all the public bodies including courts, hospitals, local governments, police, publicly-funded schools and universities, as well as other concerned bodies that performed general duties had to comply with the European Convention on Human Rights. Fundamental rights and liberties to which individual in the UK have access include (Cole, 2018):

\section{Freedoms}

- Freedom to express oneself.

- Freedom of thought, beliefs and religion.

- Freedom from being enslaved and forced labour.

- Freedom from torture and merciless or humiliating treatment.

- Freedom to express oneself.

Rights

- The rights to be saved from racial segregation regarding all rights as well as freedoms.

- The right towards enjoying one's personal property peacefully.

- The rights to get married and start a family.

- The right to have a sense of freedom and safety.

- The right to get good teaching.

- The right to have private and family life respected.

- The right to live a decent life.

- The right to have a fair trial and only be punished within the boundaries of the law.

- The right to participate in elections and vote.

\subsection{Human Rights Climate in Higher Education}

A basic understanding of the human rights basis supplies the basis upon which additional elements of human rights education must be built. "In order to be able to protect one's rights, it's necessary at the first to know what these rights are. As confirmed through the significant lawful literature and instruments, education regarding human rights cannot involve monotonous and memorization-based learning to learn the genuine human rights information but have to situate such important knowledge within a society as well contextually appropriate situation. Human rights education requires understanding more than just discuss them as lawful principles or ideologies; it has to be consists as well of cultural and social teaching. 'Linking human rights education with 'deep knowledge' of individual reality and with "hard knowledge" of realistic content is obligatory to ensure the perspective of students toward human rights education is not merely as 
distinct and conceptual of abstract concepts that are recognized as "human rights " but are an essential part in their lives (Struthers, 2015).

Education rights include four effective main actors: the government and its organizations as a supplier of public education and obligations; the parents whose role is to preserve the student's interests; and the teachers as holders of rights and duties. In this point of view, an individual allowed with rights to challenge the state and as a carrier of these rights, student, parents, and educators are allowed to ask for respect, protection and fulfilment of rights that are related to education to be met.

These obligations that are taken from the human right to teach were classified into four categories as per following (Sandkull, 2005):

Availability

- Educational institutions are obliged to guarantee obligatory and free teaching for all students in the state within a specific age range, which is at least to reach the limit that allows him to employ.

- Educational institutions are obliged to deference the choices that a parent chooses to teach their students, and take into consideration the idea of the best interest of the student.

\section{Accessibility}

- Educational institutions are obliged to eradicate the exclusion from education according to the internationally prohibited grounds of racial segregation (race, colour, sex, language, religion, opinion, origin, economic status, birth, social or HIV/AIDS, minority, indigenous or disability status).

- Educational institutions are obliged to remove gender and racial segregation in education by guaranteeing equal enjoyment of all human rights in practice.

Acceptability

- Educational institutions are obliged to set at least the minimum standards and measures for education by including the contents of course books and the curriculum, as well as strategies for teaching, discipline, professional requirements for teachers, and health and safety.

- Educational institutions are obliged to improve the kind of education by ensuring that the entire education system compatible with all human rights.

Adaptability

- Educational institutions are obliged to design and completion education for students excepted from formal teaching (e.g. refugees or displaced students).

- Educational institutions are committed to making the process of education compatible with the best interests of each student, especially when it comes to students with disabilities or special needs, minorities or native students.

- Educational institutions are obliged to employ the indivisibility of human rights as a guidance for the sake of enhancing all human rights through the means of education.

\section{Data and Methods}

\subsection{Population and Sample}

The population of the study contained of all teachers and Bachelor's degree students in the universities of Northern Jordan, which are four universities (Al al-Bayt University, University of Science and Technology, Balqa Applied University, and Yarmouk University), while the sample consisted of (521) individuals, (367) of them were students, while the remaining (154) were teachers, as it is classified into its demographic characteristics in the tables below:

Table 1. Demographic Characteristics for the Study Sample (Role)

\begin{tabular}{c|c|c}
\hline \multirow{2}{*}{ Role } & \multicolumn{2}{|c}{ Sample } \\
\cline { 2 - 3 } & Frequency & Percentage \\
\hline Students & 367 & $70.4 \%$ \\
\hline Teachers & 154 & $29.6 \%$ \\
\hline Total & 521 & $100 \%$ \\
\hline
\end{tabular}

Table (1) shows that the percentage of students from the sample was (70.4\%), while it was (29.6\%) for teachers. 
Table 2. Demographic Characteristics for the Study Sample (Gender)

\begin{tabular}{c|c|c}
\hline \multirow{2}{*}{ Gender } & \multicolumn{2}{|c}{ Sample } \\
\cline { 2 - 3 } & Frequency & Percentage \\
\hline Male & 174 & $33.4 \%$ \\
\hline Female & 347 & $66.6 \%$ \\
\hline Total & $\mathbf{5 2 1}$ & $\mathbf{1 0 0 \%}$ \\
\hline
\end{tabular}

Table (2) shows that the proportion of males from the sample was (33.4\%), while it was (66.6\%) for females.

\subsection{Research Instrument}

The University of Minnesota Scale has been used from the aims of this study, which was established by Shiman and Rudelius-Palmer (1999).

The instrument contains (25) items measuring the human rights climate in higher education institutions in Jordan. The questionnaire has been distributed by hand.

The questionnaire contains (2) demographic variables and (25) questions.

Respondents were asked to read each item, and select one of the choices according to the following scale:

- Score 4: For the (yes/always) choice

- Score 3: For the (often)

- Score 2: For the (rarely)

- Score 1: For the (no/never)

3.3 Tool Validity

Table 3. Cronbach's Alpha for the Study

\begin{tabular}{c|c}
\hline Field & Value of (a) \\
\hline The Human Rights Climate in Higher Education Institutions in Jordan & $\mathbf{0 . 7 8 8}$ \\
\hline
\end{tabular}

As revealed from the table overhead, the total Cronbach's alpha for the study fields was high, which lead to stable the result of this study.

\subsection{Data Analysis and Interpretation}

To answer the questions that inspect the human rights climate in higher education institutions in Jordan, the Statistical Set for Social Sciences (SPSS) was used in handing the following statistical techniques and tests in data analysis:

1. Reliability Test for the Instruments of Measurement: the reliability of criterion clarify the stability of consistency with which the instrument is measuring the concept and help to evaluate the "goodness" of a measure.

2. The demographical variables were described through frequencies and percentages.

3. Means and standard deviations were used to illustrate respondents to study field.

4. Independent Samples T-test: This test has been used to examine the variances present in the sample.

\section{Analysis of the Results}

In order to analyse the information and investigative questions, descriptive statistics of the questionnaire was calculated, as it's shown as follows:

Question 1: "What is the reality of human rights in Jordanian higher education institutions from students and teachers' point of view?"

To answer this question means and standard deviation were calculated for each item in the human rights climate in higher education institutions in Jordan questionnaire and Table (4) shows the results: 
Table 4. Descriptive Statistics for Identity Moratorium field

\begin{tabular}{|c|c|c|c|c|c|}
\hline $\begin{array}{l}\text { Question } \\
\text { Number }\end{array}$ & Question & Mean & $\begin{array}{c}\text { Std. } \\
\text { Deviation }\end{array}$ & Rank & Level \\
\hline 1 & My college is a place where students are safe and secure. & 3.74 & 0.91 & 1 & High \\
\hline 13 & My personal space and possessions are respected. & 3.71 & 0.83 & 2 & High \\
\hline 8 & $\begin{array}{l}\text { When conflicts arise, we try to resolve them through non-violent } \\
\text { and collaborative ways. }\end{array}$ & 3.59 & 0.93 & 2 & High \\
\hline 4 & $\begin{array}{l}\text { My college provides equal access, resources, activities, and } \\
\text { scheduling accommodations for all individuals. }\end{array}$ & 3.54 & 0.98 & 4 & High \\
\hline 9 & $\begin{array}{l}\text { Institutional policies and procedures are implemented when } \\
\text { complaints of harassment or discrimination are submitted. }\end{array}$ & 3.5 & 0.99 & 5 & High \\
\hline 10 & $\begin{array}{l}\text { In matters related to discipline (including suspension and } \\
\text { expulsion), all persons are assured of fair, impartial treatment in } \\
\text { the determination of guilt and assignment of punishment. }\end{array}$ & 3.47 & 0.97 & 6 & High \\
\hline 11 & $\begin{array}{l}\text { No one in our college is subjected to degrading treatment or } \\
\text { punishment. }\end{array}$ & 3.43 & 1.01 & 6 & High \\
\hline 18 & $\begin{array}{l}\text { I have the opportunity to express my culture through music, art, } \\
\text { and other literary forms. }\end{array}$ & 3.42 & 1.04 & 8 & High \\
\hline 14 & $\begin{array}{l}\text { My college community welcomes students, teachers, } \\
\text { administrators, and staff from diverse backgrounds and cultures, } \\
\text { including people born outside of Jordan. }\end{array}$ & 3.4 & 0.87 & 9 & High \\
\hline 23 & $\begin{array}{l}\text { Members of my college community are able to take adequate } \\
\text { rest/recess time during the college day and work reasonable hours } \\
\text { under fair work conditions. }\end{array}$ & 3.34 & 0.99 & 10 & High \\
\hline 22 & $\begin{array}{l}\text { Members of my college encourage each other to organise and take } \\
\text { action to address societal and global problems related to justice, } \\
\text { ecology, poverty, and peace. }\end{array}$ & 3.19 & 0.93 & 10 & High \\
\hline 19 & $\begin{array}{l}\text { Members of my college have the opportunity to participate } \\
\text { (individually and through associations) in democratic } \\
\text { decision-making processes to develop college policies and rules. }\end{array}$ & 3.18 & 1.05 & 12 & High \\
\hline 12 & $\begin{array}{l}\text { Someone accused of wrongdoing is presumed innocent until } \\
\text { proven guilty. }\end{array}$ & 3.11 & 0.93 & 13 & Medium \\
\hline 2 & $\begin{array}{l}\text { All students receive equal information and encouragement about } \\
\text { academic and career opportunities. }\end{array}$ & 3.03 & 0.92 & 14 & Medium \\
\hline 24 & $\begin{array}{l}\text { Employees in my college are paid enough to have a standard of } \\
\text { living adequate for the health and well-being (including housing, } \\
\text { food, necessary social services and security from unemployment, } \\
\text { sickness, and old age) of themselves and their families. }\end{array}$ & 3.02 & 0.85 & 15 & Medium \\
\hline 25 & $\begin{array}{l}\text { I take responsibility in my college to ensure other individuals do } \\
\text { not discriminate and that they behave in ways that promote the } \\
\text { safety and well-being of my college community. }\end{array}$ & 2.95 & 0.93 & 16 & Medium \\
\hline 15 & $\begin{array}{l}\text { I have the liberty to express my beliefs and ideas (political, } \\
\text { religious, cultural, or other) without fear of discrimination. }\end{array}$ & 2.91 & 0.96 & 17 & Medium \\
\hline 6 & $\begin{array}{l}\text { When someone demeans or violates the rights of another person, } \\
\text { the violator is helped to learn how to change his/her behaviour. }\end{array}$ & 2.84 & 0.92 & 18 & Medium \\
\hline 5 & $\begin{array}{l}\text { Members of my college community will oppose discriminatory or } \\
\text { demeaning actions, materials, or slurs in the college. }\end{array}$ & 2.82 & 0.88 & 19 & Medium \\
\hline 3 & $\begin{array}{l}\text { Members of the college community are not discriminated against } \\
\text { because of their lifestyle choices, such as the manner of dress, } \\
\text { associating with certain people, and non-college activities. }\end{array}$ & 2.81 & 1.09 & 20 & Medium \\
\hline 7 & $\begin{array}{l}\text { Members of my college community care about my full human as } \\
\text { well as academic development and try to help me when I am in } \\
\text { need. }\end{array}$ & 2.75 & 0.9 & 21 & Medium \\
\hline 20 & $\begin{array}{l}\text { Members of my college have the right to form associations within } \\
\text { the college to advocate for their rights or the rights of others. }\end{array}$ & 2.74 & 1.05 & 22 & Medium \\
\hline 21 & $\begin{array}{l}\text { Members of my college encourage each other to learn about } \\
\text { societal and global problems related to justice, ecology, poverty, } \\
\text { and peace. }\end{array}$ & 2.72 & 0.95 & 23 & Medium \\
\hline 17 & $\begin{array}{l}\text { Diverse voices and perspectives (e.g. gender, race/ethnicity, } \\
\text { ideological) are represented in courses, textbooks, assemblies, } \\
\text { libraries, and classroom instruction. }\end{array}$ & 2.71 & 1.02 & 24 & Medium \\
\hline \multirow[t]{2}{*}{16} & $\begin{array}{l}\text { Members of my college can produce and disseminate publications } \\
\text { without fear of censorship or punishment. }\end{array}$ & 2.5 & 0.93 & 25 & Medium \\
\hline & Total & 3.14 & 0.39 & & Medium \\
\hline
\end{tabular}

As shown from the overhead table, the overall mean for this field was (3.14) with a standard deviation of (0.39). The 
researcher also noted that question (1) which states, "My college is a place where students are safe and secure" ranked first with the average (3.74) as well a standard deviation amounting to (0.91), while question (16) which states, "Members of my college can produce and disseminate publications without fear of censorship or punishment," ranked last with the average (2.50) and a standard deviation of (0.93)..

Question 2: "Are there statistically significant differences at the level of significance $(\alpha \leq 0.05)$ of the reality of the human rights climate in higher education institutions in Jordan due to the variables of role (students, teachers) and gender?"

\subsection{Role (Students, Teachers)}

The T-test analysis was chosen to recognize the variances among the pair groups as seen in the table below:

Table 5. Results of the T-Test Analysis Differences between the Pair Groups (Role)

\begin{tabular}{|c|c|c|c|c|c|c|}
\hline Field & Role & Mean & $\begin{array}{c}\text { Std. } \\
\text { Deviation } \\
\end{array}$ & $\begin{array}{l}\text { Std. Error } \\
\text { Mean }\end{array}$ & $\mathbf{T}$ & Sig. \\
\hline \multirow{2}{*}{$\begin{array}{l}\text { The Human Rights Climate in Higher Education Institutions } \\
\text { in Jordan }\end{array}$} & Students & 3.13 & 0.39 & 0.02 & \multirow{2}{*}{0.469} & \multirow{2}{*}{0.640} \\
\hline & Teachers & 3.15 & 0.37 & 0.03 & & \\
\hline
\end{tabular}

Table (5) demonstrate the means and standard deviation of both students and teachers. The table shows that there is no important impact due to the Role variable, as the level of significance is higher than (0.05).

\subsection{Gender}

The following T-test analysis was chosen to distinguish the variances between the pair groups as seen in table (6) below: Table 6. Results of the T-Test Analysis Differences between the Pair Groups (Gender)

\begin{tabular}{|c|c|c|c|c|c|c|}
\hline Field & Gender & Mean & $\begin{array}{c}\text { Std. } \\
\text { Deviation } \\
\end{array}$ & $\begin{array}{c}\text { Std. Error } \\
\text { Mean }\end{array}$ & $\mathbf{T}$ & Sig. \\
\hline \multirow{2}{*}{$\begin{array}{l}\text { The Human Rights Climate in Higher Education Institutions } \\
\text { in Jordan }\end{array}$} & Male & 3.15 & 0.38 & 0.03 & \multirow{2}{*}{0.496} & \multirow{2}{*}{0.620} \\
\hline & Female & 3.13 & 0.40 & 0.02 & & \\
\hline
\end{tabular}

The table above displays the means and standard deviation for both males and females. It demonstrates that there isn't a significant impact because of the Gender variable, as the level of significance is higher than (0.05).

\section{Discussion of the Results}

Question 1: "What is the reality of human rights in Jordanian higher education institutions from students and teachers' point of view?"

It is shown from the results of the means and standard deviations in table (4) that the human rights climate is present at higher education institutions in Jordan at a medium degree of (3.14) and a standard deviation of (0.39), where (12) paragraphs obtained a high degree, and (13) paragraphs obtained a medium degree; none of the paragraphs got a low degree.

Question (1), which states, "My College is a place where students are safe and secure," came first with an average (3.74) and a standard deviation of (0.91). This result is a reflection of the general situation in the Hashemite Kingdom, as the sense of security is a common feeling among all citizens. The community within the college may also have some privacy, as the vast majority of students are female, while there are very few male students in comparison to their female counterparts, in addition to the small size of the college community and the homogeneity among students.

Question (13), which states, "My personal space and possessions are respected," came second with an average (3. 71) and a standard deviation of $(0.83)$; this shows that members of the higher education institutions, whether they were students or teachers, have a high respect for other's personal space and possessions and that they respect others' privacy as well. It can be also due to the fact that the laws, regulations, and instructions within the college prevent abuse or infringement of its members' personal property and space; in addition, community ethics reject such behaviour, where the person who carries out such conduct can be convicted both socially and legally.

Question (17), which states, "Diverse voices and perspectives (e.g. gender, race/ethnicity, ideological) are represented in courses, textbooks, assemblies, libraries, and classroom instruction," came second to last with an average (2. 71) as well a standard deviation amounting to (1.02). This reflects the atmosphere of tolerance and acceptance of others regardless of gender, cultural background, ethnicity, and ideologies, which is supported by being embodied in courses, textbooks, assemblies, libraries, and classroom lessons. This also indicates that people of Jordan and especially in college communities are tolerant of minorities who are not the same as them in terms of cultural diversity but instead sees it as an enrichment of identity filled with the spirit of love, tolerance, and solidarity. 
On the other hand, question (16) which states, "Members of my college can produce and disseminate publications without fear of censorship or punishment," came last with an average (2. 5) as well a standard deviation of (0.93). This result may be attributed to the fact that regulations prohibit publications unless they are approved by the college administration or are concerned with academic matters, resulting in those on campus to object against what they consider to be discrimination or damage from scientific acts or materials or college posters. It can be also due to the fact that members of higher education institutions are still somewhat hesitant when it comes to freedom of speech and expressing themselves.

This result is consistent with the result of the Author's (2014) study, which showed that human rights are present in the community of the Jordanian university at the moderate level of (63\%).

It is also consistent with the results of the survey conducted by the Centre for Strategic Studies at the University of Jordan in cooperation with the National Centre for Human Rights (2010) regarding the situation of human rights in Jordan, where $(600 \%)$ of the sample believed that human rights are protected in Jordan.

Question 2: "Are there statistically significant differences at the level of significance $(\alpha \leq 0.05)$ of the reality of the human rights climate in higher education institutions in Jordan due to the variables of role (students, teachers) and gender?"

The results of the means and standard deviations that have been presented in tables (5) and (6) show that there aren't any significant differences between the impact of the human rights climate on institution of higher education in Jordan due to the variables of role (students, teachers) and gender (male, female).

The Role variable had a (0.640) level of significance, which is higher than (0.05), where students had an average (3.13) as well a standard deviation of (0.39), while teachers had a mean of (3.15) and a standard deviation amounting to (0.37), which indicates that there aren't any significant differences. This can be due to the fact that both students and teachers are acutely and equally aware of others' humane rights, as both of these groups are adults, and therefore they're more mature and respectful of others' rights.

On the other hand, the Gender variable had a (0.620) level of significance, which is higher than (0.05), where males had an average (3.15) and a standard deviation of (0.38), while females had a mean of (3.13) and a standard deviation of (0.40), which implies that there aren't any significant differences. This can be due to the fact that both male and female are acutely and equally aware of others' humane rights.

\section{Conclusion}

The importance of human rights is beginning to receive even more attention by different parties as the days go by, especially in educational institutions in general, and higher education institutions in specific, as they are considered to be the most fundamental institutions in any society due to their vital role of raising a compassionate offspring that will have a positive impact on the society in the future. Thus, the issue of human rights has become a crucial requirement for any society to grow and flourish with a positive impact.

The present study was made as an attempt to explore the impact of the human rights climate in the institutions of higher education in Jordan. In light of the results shown in this study, it has been concluded that people within higher education institutions are aware of the concepts of human rights and to apply them; however, given how most results were medium, there is room for improvement. In this retrospect, the institution of higher education have to pay more attention to the concept of human rights and seek to apply it within their walls by either implementing human rights education in its curriculum and hold seminars that aim to educate and familiarize students with the concept of human rights, thus eliminating any source of discrimination or injustice.

\section{Research Limitations and Direction for Further Research}

There were some limitations within this study that must be taken into account; first being the human limitation, where the population of the study was limited to include student and teachers at higher education institutions in Jordan only. The second limitation would be insincerity and conflict when answering the questionnaire by some of the sample members, resulting in these questionnaires being excluded by the researcher and not being included in the final analysis. The third limitation was the lack of resources to work with, as the topic of human rights and their impact on higher education institutions was scarcely discussed.

While including both students and teachers at higher education institutions was an effective method, it would have been more effective to include a sample larger than (179) so as to acquire better outcomes. It would also be preferable to include other educational institutions, such as training institutions and colleges from across the entire Hashemite Kingdom of Jordan. Further qualitative research would be needed in the future to accurately measure the climate human right's impact in higher education institutions in Jordan. 
Further research into the broader impact of the human rights climate on the institution of higher education in Jordan as well as new outcomes, whether they are positive or negative, would be highly appreciated by the researcher.

\section{References}

Cole, M. (Ed.) (2018). Education, Equality and Human Rights: Issues of Gender, 'Race', Sexuality, Disability and Social Class $\left(4^{\text {th }}\right.$ Ed.). Abingdon, United Kingdom: Routledge.

Gündoğdu, K. (2011). Candidate Teachers' Attitudes Concerning Human Rights Education in Turkey. Education and Science, 36(162), 182-195.

Lynch, C. (2017). A Global Perspective: Investigating Human Rights Education in Higher Education Institutes. Unpublished Master's Thesis, University of Manitoba, Winnipeg, Canada.

Mubangizi, J. (2013). The Protection of Human Rights in South Africa: A Legal and Practical Guide. Cape Town, South Africa: Juta \& Company.

Mubangizi, J., \& Kaya, H. (2015). African Indigenous Knowledge Systems and Human Rights: Implications for Higher Education, Based on the South African Experience. International Journal of African Renaissance Studies-Multi-, Inter- and Transdisciplinarity, 10(2), 125-142. https://doi.org/10.1080/18186874.2015.1107985

National Center for Human Rights. (2010). Seventh Annual Report of the National Center for Human Rights: Human Rights Situation in the Hashemite Kingdom of Jordan for 2010. Report, National Center for Human Rights, Amman, Jordan.

Nduta, J. (2015). School Factors Influencing Integration of Human Rights Education in Public Secondary School Curriculum in Kasarani Sub-County, Nairobi City County Kenya. Unpublished Master's Thesis, University of Nairobi, Nairobi, Kenya.

Ocampo, J. (2004). ABC: Teaching Human Rights: Practical Activities for Primary and Secondary Schools. Virginia, United States of America: United Nations Publications.

Office of the United Nations High Commissioner for Human Rights (2002). Leaflet No 2: Indigenous Peoples, the UN and Human Rights. Report, Office of the United Nations High Commissioner for Human Rights, Geneva, Switzerland.

Patel, J. (2007). Human Rights Education. Paper presented at the "Human Rights and Values in Education" Conference, Shri H. S. Shah College of Commerce, Modasa, India.

Sandkull, O. (2005). Strengthening Inclusive Education by Applying a Rights-Based Approach to Education Programming. In ISEC Conference, Glasgow (pp. 1-9).

Shiman, D., \& Rudelius-Palmer, K. (1999). Economic and Social Justice: A Human Rights Perspective. Minneapolis: Human Rights Resource Center, University of Minnesota.

Struthers, A. (2015). Human Rights Education: Educating about, Through and for Human Rights. The International Journal of Human Rights, 19(1), 53-73. https://doi.org/10.1080/13642987.2014.986652

Tarrow, N. (Ed.) (2014). Human Rights and Education ( $1^{\text {st }}$ Ed., Vol. 3). Oxford, United Kingdom Pergamon Press.

United Nations. (2018). Your Human Rights [online]. Retrieved 20/05/2018 from http://www.ohchr.org/EN/Issues/Pages/WhatareHumanRights.aspx

\section{Copyrights}

Copyright for this article is retained by the author(s), with first publication rights granted to the journal.

This is an open-access article distributed under the terms and conditions of the Creative Commons Attribution license (http://creativecommons.org/licenses/by/4.0/). 